\title{
Preservice teachers' beliefs in the context of teaching mathematics to English learners in the United States
}

\author{
Anthony Fernandes, University of North Carolina at Charlotte (USA) \\ Leslie H. Kahn, Tucson Unified School District (Retired) (USA)
}

\begin{abstract}
This study examines the beliefs of fourteen preservice teachers in the Southeast United States about mathematics and language in the context of teaching mathematics to English learners. Qualitative interviews were conducted using survey items as a starting point for the questioning. Speer's (2008) construct of collections of beliefs was used to understand the preservice teachers' belief system and the interaction of beliefs. Three primary beliefs emerged: mathematics is universal, mathematical language, and language barrier. Their belief about mathematics being universal was grounded in their view that mathematics was mostly about symbols and equations. The preservice teachers believed that there was some language in mathematics, though these features were not as pervasive as the symbolic form. Most of them also believed that the English learners were recent immigrants to the country and that English was a barrier for the students in the mathematics classroom. The beliefs interacted in three ways as they responded to the items: dominance, tension, and convergence.
\end{abstract}

Keywords. English learners; teaching mathematics; language; beliefs; interviews.

Creencias de futuros profesores de matemáticas en el contexto de enseñar matemáticas a aprendices de inglés en los Estados Unidos

\section{Resumen}

Este estudio examina las creencias de catorce futuros profesores en el Sudeste de Estados Unidos sobre matemáticas y lengua en el contexto de enseñar matemáticas a aprendices de inglés. Se realizaron entrevistas cualitativas con ítems de encuesta como punto de partida de las preguntas. El constructo de colecciones de creencias de Speer (2008) sirvió para comprender el sistema de creencias de los futuros profesores y la interacción entre creencias. Emergieron tres creencias básicas: la matemática es universal, la lengua matemática y la barrera de la lengua. La creencia sobre la universalidad de la matemática estaba basada en su visión de que la matemática trata sobre todo con símbolos y ecuaciones. Los futuros profesores creían que había algo de lengua en la matemática, aunque estos rasgos eran menos presentes que la forma simbólica. La mayoría también creía que los aprendices de inglés eran migrantes recientes en el país y que el inglés era una barrera para ellos en clase de matemáticas. Las creencias interactuaron de tres maneras en las respuestas a los ítems: dominación, tensión y convergencia.

Palabras clave. Aprendices de inglés; enseñar matemáticas; lengua; creencias; entrevistas.

\section{Introduction}

Teachers' beliefs influence the choices they make during their teaching (Aguirre \& Speer, 1999; Cooney \& Shealy, 1997; Cross, 2009; Pajares, 1992; Reeves, 2006; Thompson, 1992). As we prepare preservice teachers (PSTs) to work in future classrooms, we attempt to understand their beliefs about mathematics and language within the context of teaching mathematics to emerging bilingual students in the United States. Emerging bilingual students are generally referred to as English Learners (ELs) or English Language Learners (ELLs) in policy or standard documents, and we use ELs to denote emerging bilingual students. Although the population of ELs continues to increase, teachers have differing views about their inclusion in the classroom. In Reeves (2006), teachers believed that ELs created a positive atmosphere in the class that would 
lead to learning of all students. Other teachers, however, believed that ELs should first work to develop their English proficiency and enter classes with an advanced level of proficiency (Gandára, Maxwell-Jolly, \& Driscoll, 2005; Polat \& Mahalingappa, 2013; Walker, Shafer, \& Iiams, 2004). Further, teachers associated the learning capability of the ELs based on their ability to communicate in English, believing that students who were proficient in English would be more successful at school (Cummins, 2000; González \& Darling-Hammond, 2000; Ruiz, 1988). Based on their beliefs of the ELs' ability to master the content, teachers tended to assign ELs to instructional tracks with less rigorous mathematics curriculum (Gutiérrez, 2002), negatively affecting their identities of themselves as mathematics learners (Yoon, 2007).

In the case of mathematics instruction, the teachers' beliefs about the role of language as a prerequisite to success, could lead to mathematics teachers providing reduced language support for ELs. Educators assumed that mathematics involved less language compared to other subjects like social studies, and hence believed mathematics would be easier for ELs (e.g. Penfield, 1987; Sawyer, 2000). Moschkovich and Zahner (2018) point out, however, that mathematics education requires active participation in learning, with language intensive activities like providing justification and building on others' reasoning. Griego-Jones (2002) makes the case that PSTs will not connect to the extensive body of knowledge about teaching ELs if they believe that it is not relevant to their future teaching. This may be especially true with PSTs moving into mathematics education. This study serves to further inform educators about PSTs' beliefs in teaching mathematics to ELs. Our research question is: What beliefs do preservice teachers have about mathematics and language in the context of teaching English learners?

\section{The construct of beliefs}

Beliefs are a psychological construct widely used in research. Despite its extensive use, researchers still debate how it should be defined (Pajares, 1992). We use the definition by Philipp (2007), where beliefs are "psychologically held understandings, premises, or propositions about the world that are thought to be true" (p. 259). Here, "beliefs might be thought of as lenses that affect one's view of some aspect of the world or as dispositions toward action" (p. 259). Green (1971) posits that beliefs exist as part of a larger beliefs system. They are not held in isolation but exist as a cluster that relate and build upon each other. However, it is possible that a cluster can remain independent of another cluster, unless they are brought to the attention of the person.

Beliefs have a quasi-logical structure, where some beliefs (derived beliefs) follow from other beliefs (primary beliefs). The quasi-logical structure means that derived beliefs may not follow from the primary beliefs as they are unstable and may influence each other. Moreover, beliefs are held with relative strengths, which are not determined by its primary or derived status. It is thus possible for primary beliefs to be peripheral and derived beliefs to be more central. Strongly held beliefs are considered more central within the beliefs system, have a high degree of connectedness, are difficult to change, and may contradict one another. On the other hand, peripheral beliefs are less strongly held, remain less connected, and are easier to change.

Identifying beliefs can be challenging, as people may not be aware of the beliefs they hold. Without being able to identify one's particular belief, research suggests there is a need to infer beliefs based on what a person says and the actions they take within a context (Cooney, Shealy, \& Arvold, 1998; Pajares, 1992). Sztajn (2003) illustrated a case study of two teachers, engaged in long-term professional development, with similar 
beliefs about the value of mathematics reform, who implemented the curriculum differently. The teacher of students of middle-income families engaged them with problem solving. The teacher of students of low-income families implemented a curriculum of learning basic facts and repeated practice. Despite similar beliefs, one teacher was unable to implement reforms based on their belief about the students' socioeconomic status. This belief had not been addressed prior to implementation, and thus the teacher provided a different mathematics education experience for the students.

In mathematics education, the research on beliefs has focused on the connection between teacher's beliefs and practices. Researchers have concluded in some cases teachers' beliefs and practices align and at other times they do not (Thompson, 1984). Speer $(2005,2008)$ attributed the contradictions in the connections between beliefs and practices in prior research to the very general way in which both beliefs and practices are conceptualized by researchers. Speer (2008) pointed out that knowing a teacher has "learner-centered" beliefs about teaching and learning does not provide insight into their beliefs about questioning practices that the teacher would use to create a "learnercentered" classroom. Based on studies with a teacher, Speer focuses on the mechanism by which the beliefs influence the moment-to-moment decisions of the teacher.

The construct of collection of beliefs captures the small set of beliefs that together describe a teacher's perspective on a particular topic (Speer, 2008). The collection has components taken from different parts of beliefs systems and can combine in various ways to inform the goals and decisions of the teacher in-the-moment. In one example, a student presented a solution that did not use the formula discussed in class, which in turn changed the teacher's goal in the moment to assist the student with the correct formula. As the shift occurred, the researchers were able to observe beliefs activated in the moment. The collections of beliefs in this case consisted of components of mathematics, learning, and teaching beliefs that influenced the formulation of the teacher's new goal. Thus, Speer encourages examining beliefs using the construct of collections of beliefs to reflect the complexity of a teacher's practice. We are reminded by Sztajn (2003) that beliefs about mathematics reform are but one aspect of the collection of beliefs that teachers hold along with how students interact that determines the outcome of the teachers' practice. We draw on the collections of beliefs construct in this study as we examine the PSTs beliefs in the context of teaching mathematics to ELs.

\section{Literature review}

Most of the research about beliefs related to the education of ELs focus on all teachers and PSTs, rather than just those teaching and preparing to teach mathematics. Literature focuses on beliefs about inclusion of ELs in content classes, accommodations for ELs, use of the students' native language in the classroom, and responsibility of teachers with respect to ELs in the class. Bilingual education studies show teachers supportive of the theoretical underpinnings of bilingual education (Karabenick \& Noda, 2004; Shin \& Krashen, 1996). These teachers believed that literacy in the native language facilitated the development of literacy in English. Teachers also believed that if ELs learned the content in their native language, they would understand the content when it was taught in English. However, despite these beliefs about the support for transfer of knowledge across languages, and understanding the premise using native language in the classroom, teachers rarely supported this practice. Shin and Krashen (1996) discussed teachers' beliefs in relation to the factors that may promote the practical beliefs about teaching ELs and thus their implementation in the classroom. 
Griego-Jones (2002) focused on the language beliefs of PSTs. Ninety-one PSTs, at the beginning of their teacher preparation, were surveyed about ELs and learning a second language. A subset of the PSTs who had prior experiences with ELs were more likely to have beliefs that align with the theoretical and practical aspects of bilingual research believing it was important to develop a child's native language in school and use it in teaching ELs. Most of the PSTs with prior experiences with ELs did not have deficit language beliefs. Preservice teachers believed that using the native language and English in the class would support the ELs. They did not believe that ELs would learn English faster if they were taught only in English, or that speaking the native language would keep the ELs from learning English.

Fernandes (2020) study focused on mathematics PSTs and their beliefs about ELs' use of the native language in the mathematics classroom. Using Ruiz's (1984) framework on language orientations to analyze the 31 qualitative interview responses, we outlined four typologies that expanded Ruiz's language orientations of language-asproblem to language-as-resource and ranged on a continuum from only English to fluency in bilingualism. Preservice teachers who supported the use of the native language in the class were mainly focused on how the native language could help the ELs connect to the mathematics they had learned in their home countries.

Quantitative studies that had a few items related to teachers' beliefs about teaching mathematics to ELs determined that mathematics would be easier to teach ELs compared to other subjects (Penfield, 1987; Tan, 2011). There are various quantitative studies and mixed studies that throughout the last decades have informed mathematics teachers' beliefs about teaching school mathematics to learners who are in the process of learning the language of instruction. Nonetheless, the prior literature in the area has been focused on the beliefs of mainstream teachers, without a special focus on mathematics teachers. When the studies reported are specific of mathematics teachers, they are not oriented to examine the beliefs that PSTs have about language and mathematics in the context of teaching ELs. The beliefs that are described are usually at a general level and there is no discussion about the interaction of beliefs. As a contribution to this gap in the research literature, our study seeks to examine how the PSTs beliefs interact with each other and may inform practices in the classroom.

\section{Questionnaire tool and interviewing methods}

Semi-structured interviews were conducted with 14 PSTs at a university in the Southeast United States. Ten were one-on-one and two interviews were conducted in pairs due to scheduling constraints. With little discussion between the PSTs in the paired interview, we consider these individually for the purposes of analysis. Instructors at the first author's university teaching the mathematics content and methods courses were asked to share information about the study with their PSTs. Interested PSTs volunteered and were given a small remuneration to do the interview. The demographics of the participants are outlined in Table 1. Most of the participants were White, female, and monolingual in English. All the PSTs were preparing to teach elementary and middle school and had some experience in the classroom through their degree programs. Their experiences included clinical observations, as required by some courses, and classroom observations within yearlong internships. The internship includes two semesters, with classroom observations in the first semester and student teaching in the same classroom in the second semester. Most of the PSTs did not have any prior experience as a classroom teacher or a substitute teacher. There was a balance of PSTs exposed to issues of ELs through multicultural courses and [issues of ELs in] special education courses. 
According to Youngs and Youngs (2001), teachers with prior experience learning a second language are more understanding of the challenges that ELs face in learning in a new language. Thus, we were interested in understanding the language learning experiences of the PSTs. All the PSTs had some formal experience learning another language as part of their high school requirements. However, in most cases they were not fluent in the language. Only two PSTs were fluent in another language, and both had moved to the United States from Asian countries.

Table 1. Demographic and other details of interviewed preservice teachers

\begin{tabular}{|l|l|}
\hline Gender & Male, 3; Female, 11 \\
\hline Race & $\begin{array}{l}\text { White, not of Hispanic origin, 10; } \\
\text { Asian or Pacific Islander, 2; Biracial } \\
\text { /Multiracial, 1; No response, 1 }\end{array}$ \\
\hline Grade levels preparing to teach & K-5, 8; 6-8, 6 \\
\hline $\begin{array}{l}\text { Class experience through degree program } \\
\text { Years of experience either as a classroom } \\
\text { teacher or substitute }\end{array}$ & None, 11; 0-4 years, 2; 5-10 years, 1 \\
\hline $\begin{array}{l}\text { Exposed to EL issues through coursework } \\
\text { Fluent in a language other than English }\end{array}$ & Yes, 7; No, 7 \\
\hline Experience learning a second language & Yes, 14; No, 12 \\
\hline
\end{tabular}

Questions are integral to an interview and we had to work around constraints in their design because the PSTs had limited experiences with ELs and were not familiar with terminology in the area (e.g. conversational language and academic language). Moreover, we did not want the PSTs to provide responses that they thought the interviewer wanted. We conjectured that asking the PSTs to react to a statement, along with probing questions, would elicit responses that would help us make inferences about their beliefs. We viewed the statements as possible derived beliefs that the PSTs could have, and based on their responses, we could infer their primary beliefs about mathematics and language in the context of teaching ELs.

The scale consisted of 30 belief items, nine demographic items, and a constructed response about their definition of an English learner. A five-point Likert scale was used for the belief items (Strongly Disagree=1, Disagree=2, Undecided=3, Agree=4, Strongly Agree=5). The items were adapted from the literature and the personal experience of mathematics educators who were consulted on the design. The underlying framework for the design of the items was based on a non-deficit view about ELs and their communities (Civil, 2007). According to this view, ELs and their communities have valuable resources (e.g. native language) that are assets available for teachers to use and to develop the students' knowledge in the classroom. We chose the following 13 (out of the 30) items that examined the PSTs' beliefs about language and mathematics and linguistic resources (e.g. gestures) in the context of teaching mathematics to ELs:

- Item 1. Math is not language intensive

- Item 2. Language demands for ELs in math only occur in word problems

- Item 3. ELs are challenged by specific math terms (e.g. table, denominator) and phrases (e.g. if... then...)

- Item 4. ELs and non-ELs face the same challenges as they learn math

- Item 5. Math is the best subject to help new ELs begin to use English

- Item 6. ELs can be effectively taught math in English before they are fluent in English. 
- Item 7. After one year of English classes and interactions in English at school, ELs should be capable of engaging in classroom math discussions

- Item 8. ELs should be capable of engaging in class math discussions once they learn the math vocabulary

- Item 9. When ELs switch between languages to explain their mathematical thinking, it shows a lack of mathematical understanding

- Item 10. Non-verbal communication (e.g. drawings, symbols, gestures etc.) are valuable resources for ELs to demonstrate their math thinking

- Item 11. All math classrooms should allow ELs to discuss ideas with each other in their native language

- Item 12. Whenever possible, new ELs should be taught math in their native language and English

- Item 13. ELs will not learn English quickly if I allow them to speak their native language in my math class

On average, the PSTs took about 50 minutes to complete the interview. All the interviews were conducted by the first author in an office and were videotaped. The items above were used as a springboard for engaging the PSTs in a discussion about their beliefs. Given that beliefs influence dispositions to act in certain contexts, the items were designed to prompt these contexts to understand how the PSTs would react. For example, the item that asked if the ELs would be capable of having math discussions after a year of learning English (item 7), was meant to elicit the PSTs' thinking about the academic language and the time it took ELs to be proficient in this to engage in a mathematical discussion. Based on the PSTs' responses to the items, there was some flexibility in the probing questions (Zazkis \& Hazzan, 1999). PSTs read an item, responded with a choice on the Likert scale, and were asked to explain their choice. Based on interactions with PSTs around earlier versions of the survey, we were aware of possible responses and posed questions that probed the PSTs further.

Part of the probing strategy was to determine the strength of their belief. If the PST agreed that ELs could discuss mathematics in their native language in class, they were asked to respond to a scenario in which another teacher who commented that the ELs should be speaking English in school. Listening to their responses allowed us to draw inferences about their beliefs and the relative strength. These strategies were used consistently across all the interviews. In this way direct conflicts were avoided while the PSTs were invited to respond to a realistic scenario. This approach could be characterized as asking reflection questions (Zazkis \& Hazzan, 1999). Overall, the probing questions were used to get more detail and clarification about how the PSTs were thinking about an issue. Thus, providing a more in-depth description that we could use to make inferences about their collection of beliefs related to the context of the item.

\section{Data analysis}

The focus of the study was to understand the PSTs' collection of beliefs about mathematics and language in the context of teaching ELs. Research assistants transcribed all the qualitative interviews for analysis. The first author conducted the primary analysis by watching the videos of the interviews and verifying the transcriptions. Given the large volume of qualitative data, the PSTs' responses to each item, both the qualitative and quantitative, were summarized in a matrix with 364 cells, 14(PSTs)x13(items)x2(quantitative and qualitative). The qualitative summaries in the matrix cells captured the essence of the PSTs' response to the item. While it is possible that the summary missed some details, the tradeoff was that it allowed for the inquiry of 
broader trends across items and PSTs. The analysis involved observing trends in the essence of responses, within and across PSTs. Attention was also paid to the quantitative responses that the PSTs were giving on the Likert scale. The next level of analysis was to infer the various beliefs that we anticipated were driving the PSTs' reasoning in a response. To make these inferences, we also examined the PSTs' responses to the other items to maintain a consistent approach and ground our thinking in the data.

We inferred three primary beliefs in the collection of beliefs that were interacting in various ways in the PSTs' responses. The three primary beliefs were categorized as mathematics is universal, mathematical language, and language barrier. We provide a brief example that outlines our coding process that started with the matrix cells and also involved examining the transcript and video in some cases. In the cell for Ingrid's response to item 2, the summary recorded was: "Even when you are talking about a problem you still have to explain it. Even in long division there is a process that you have to explain. It would be harder in general for the ELs, given that they do not know the language." Here Ingrid made a reference to the ELs not knowing the language (English), which we associated with her belief that ELs faced a language barrier when using English. She also mentioned that the students needed language to explain long division, even though they could work through the steps correctly. Based on her responses to other items, where she mentioned multiplication involving less language and that mathematics was universal, we associated her reference to division as another mathematical operation, which reflected her belief that mathematics was universal.

Table 2. Matrix cell coding frequencies for PSTs

\begin{tabular}{|l|l|l|l|l|l|l|l|}
\hline & Language & Math & Vocab & Tension & Convg & Uncoded & Total \\
\hline Ingrid & 7 & 2 & 0 & 1 & 3 & 0 & 13 \\
\hline Jane & 7 & 2 & 1 & 2 & 1 & 0 & 13 \\
\hline Ginny & 2 & 3 & 1 & 0 & 0 & 7 & 13 \\
\hline Ophelia & 7 & 1 & 0 & 2 & 3 & 0 & 13 \\
\hline Mel & 4 & 4 & 1 & 0 & 2 & 2 & 13 \\
\hline Kirk & 5 & 3 & 1 & 0 & 0 & 4 & 13 \\
\hline Jason & 7 & 1 & 2 & 1 & 1 & 1 & 13 \\
\hline Sandra & 12 & 0 & 0 & 0 & 1 & 0 & 13 \\
\hline Teresa & 3 & 1 & 1 & 1 & 1 & 6 & 13 \\
\hline Hilda & 6 & 4 & 0 & 0 & 1 & 2 & 13 \\
\hline Kate & 6 & 2 & 1 & 0 & 1 & 3 & 13 \\
\hline Andy & 3 & 1 & 2 & 0 & 0 & 7 & 13 \\
\hline Kristen & 6 & 2 & 1 & 0 & 0 & 4 & 13 \\
\hline Lydia & 7 & 0 & 1 & 0 & 0 & 5 & 13 \\
\hline & 82 & 26 & 12 & 7 & 14 & 41 & 182 \\
\hline
\end{tabular}

In addition to identifying the primary beliefs that made up the collection, we examined the interactions among the primary beliefs and inferred three ways in which they interacted: dominance, tension, and convergence. Color codes were used with the matrix cell to highlight the interaction of beliefs. Table 2 outlines the color codes and frequencies for each PST. 'Language', 'Math' and 'Vocab' represent the dominance of each of the primary beliefs: language barrier, mathematics is universal and mathematical language. 'Tension' refers to the tension between two primary beliefs, and 'Convg' represents the convergence of beliefs. The column 'Uncoded' represented the cells that we could not code using our scheme and negative or disconfirming cases (Glaser \& Strauss, 2017). Some of the uncoded cells represented responses that were either too 
brief to make an interpretation, or related to another topic that resulted from the probing as the PST expressed difficulty with the item (e.g. the classroom management of ELs). However, the response of an elementary PST, Ginny, remained 'Uncoded' because the beliefs inferred did not fit the typical pattern of beliefs of the other PSTs. We considered her response as evidence of a 'negative' or disconfirming case that did not fit the coding scheme for the other PSTs. Though she believed that the ELs are challenged with the language, she actively promoted the use of two languages and moved away from the belief that the ELs had a language barrier with English. She also believed that the mathematics and language were intertwined and that the academic vocabulary, though important, was just one part of the mathematics language challenge for ELs.

During the analysis we often returned to the portions of the transcript, and video, to clarify our interpretations. We discussed the PSTs' responses where we differed in our independent analysis to arrive at a consensus. Both authors had regular discussions during the analysis phase to clarify and refine the interpretations.

\section{Results}

Based on the analysis of the PSTs' responses, we inferred three primary beliefs; two about the nature of mathematics and one about ELs: mathematics is universal, mathematical language, and language barrier. We begin with a description of the primary beliefs, and then describe how the various beliefs in the collection interacted with each other as the PSTs responded to the interview questions.

\subsection{Mathematics is universal}

"Mathematics is universal" was a statement of some PSTs in the interviews. Even the PSTs who did not state this explicitly, discussed mathematics in a way where we could infer this belief about the nature of mathematics. A key aspect of the belief was that mathematics consisted of numbers and operations that remained the same in all countries, hence was universal. Teresa shared that the numbers remained the same, even though they had different labels in the different languages (e.g. two is dos in Spanish), and the underlying mathematics operations (e.g. addition) and concepts also remained the same. Jane added, "I think math is universal because of the numbers and you get the same answer no matter where you are, or the language you speak." In addition to numbers and operations, the middle school PSTs mentioned that the ideas in algebra and geometry were the same in different countries; justifying, for them, that mathematics was universal. The PSTs believed that the ELs essentially learned the same mathematical content in a different language. Most of them believed that ELs would come to the U.S. knowing some mathematics that they learned in their home countries, making it easier for the ELs to adjust to schooling in the U.S. Hilda, a middle grades PST claimed,

Well I said agree (with item 5) because the concepts in math are usually universal. So, it's easier for a foundation that you can kind of stand on and then build from there. Then it's just, I guess teaching them the different like the words in that language if they are actually learning them because they mean the same thing across the spectrum.

Hilda believed that the concepts taught in mathematics were the same, hence universal. The only difference was in the language used for the associated mathematics vocabulary in the home country and the U.S. In this instance we also infer that Hilda gives an importance to the mathematical vocabulary. 
In addition to the numbers, other middle grades PSTs, like Mel, pointed out that mathematics also involved symbols and formulas that have no language and could be taught to ELs before they were fluent in English. Preservice teachers in general tended to believe that the ELs were good at mathematics as Jane said, "Sometimes the ELs do well in math, because it is universal. ELs seem to know the math from my experiences." Like Jane, some of the other PSTs believe that the ELs would know the mathematics.

\subsection{Mathematical language}

Though the PSTs believed that numbers, symbols, equations, and operations dominated mathematics, they also believed that mathematics included some linguistic features. They shared a primary belief that vocabulary and word problems dominated the mathematical language. Preservice teachers also noted that the mathematical language would be equally challenging for all the students, whether they were ELs or not. They often cited their own challenges in mathematics to make their point. The PSTs believed that the vocabulary played a key role for ELs to engage in mathematical discussions in class. For example, when asked if language challenges of ELs were limited to word problems (item 2), Mel pointed to the importance of mathematical vocabulary for discussions - "I mean to have a math discussion, they have to know basic terms. They have to know the definition of terms." Mel confirmed that he was using "basic terms" to refer to the mathematical vocabulary.

Though the PSTs believed that mathematics had linguistic features, vocabulary and word problems, the PSTs believed that these features were not as dominant as those that made mathematics universal, like numbers, symbols, equations, and formulas. Further, they also noted that vocabulary and word problems also remained challenging for all students and not just the ELs. When discussing if ELs and non-ELs faced the same challenges in mathematics (item 4), Mel brought up his belief about the nature of mathematics and said, "I think with math it's only two ways - computation and vocabulary." He added that if the ELs can do both the computation and know the vocabulary, they are "just like me". This highlights the important role that vocabulary played in the PSTs' beliefs about the mathematical language.

\subsection{Language barrier}

Within the context of teaching mathematics to ELs, the belief that ELs have a language barrier with English was a dominant belief among the PSTs. In particular, the PSTs believed that the ELs were recent immigrants and as such had low levels of English proficiency. Ingrid, a middle grades PST, in response to item 7, was undecided on whether the ELs would be able to engage in mathematics discussions after a year "because there still might be that language barrier." Jason, an elementary PST, added that ELs are "unclear with English as a whole". He outlined the challenges:

If they are not understanding you a hundred percent, then they are going to have a problem. They will have a hard time understanding the terms you are trying to define

The PSTs believed that the low English proficiency of the ELs would constrain their engagement with peers and the teacher, who in most cases would be monolingual English speakers and viewed it as a barrier. Further, they distinguished the challenges between the mathematical language and their challenge with speaking and interacting in English. When asked if ELs and non-ELs face the same challenges in learning mathematics (item 4), Ophelia mentioned that everyone has a challenge learning mathematics "whether you're an EL or not", however, "ELs just have like an added challenge to that. Like they have the language barrier on top of like just the normal math 
challenges that a lot of people have." thus distinguishing the mathematical language and the general English proficiency. Given this belief about the English proficiency of the ELs, there were some beliefs about the ELs assimilating and learning English. Most of the PSTs agreed that it was important for the ELs to develop their English proficiency as soon as possible with the hope that the ELs would be able to interact and participate in English only mathematics classes.

\subsection{The interaction between the beliefs}

Speer (2008) highlighted how beliefs in different clusters come together to inform teachers' moves in the moment. Our analysis continues to build on their work, by examining the collection of beliefs that PSTs have in the context of teaching mathematics to ELs. In addition to identifying the beliefs in the collection, we classified the different ways in which the beliefs within the collection interacted with each other. We found: dominance of a belief, the convergence of beliefs, and tension between beliefs. Dominance referred to one belief being dominant in the PSTs' response to an item. Convergence referred to the primary beliefs pulling in the same direction to inform the PSTs' response. Tension between beliefs referred to two primary beliefs that pulled the PSTs' response in different directions. In this case, the PSTs responded to the item by being undecided. We observed that the context of the item and the PSTs' own experiences seemed to guide the interaction of the beliefs.

Dominance. There were three types of dominance patterns in the responses, 82 instances where the belief that the ELs had a language barrier in English, 26 associated with the belief that mathematics is universal, and 12 related to their beliefs about the mathematical language (Table 2). The same item could prompt the dominance of different beliefs in the collection from different PSTs. Preservice teachers' response to the ELs being taught mathematics before they were fluent in English (item 6), was an item that fore-fronted the dominance of two different beliefs by the PSTs. Sandra, an elementary PST, had spent a year in Belgium attending school where the language of instruction was French. Based on her experience, language as barrier was a dominant belief in this collection where Sandra also refers to the universality of mathematics:

When I was in Belgium, I got nothing out of it really. It was like waste of a whole year of math and everything else honestly that was taught in French. Because I just couldn't understand. I didn't do well because I couldn't... write well in French. I just couldn't communicate. You might pick up on somethings in lessons and such, but you may not completely understand. You might leave things out, leave steps out or something because you didn't understand. So, I would put disagree.

Sandra's experience had a strong influence in her response to the item. Her belief that ELs had a language barrier dominated her belief that mathematics was universal. The strength of her belief of language of teaching being a barrier came through in her emotional expression of a "waste of a whole year". She mentions, "you might pick up on some things in lessons", referring to some aspects of mathematics, like numbers, which relate to the belief of mathematics being universal. Overall, Sandra did not believe that ELs could effectively learn mathematics given their language barrier. She used her experience as a language learner to make her point. In contrast to Sandra, Ophelia's response to item 6 was dominated by her belief that mathematics is universal and that ELs, despite being in the process of learning English, could be taught mathematics before they were fluent: 
I think you need to like, know some English, but I don't think you necessarily need to be completely fluent because I think a lot of math can be demonstrated without using words. I think if the teacher is using pictures and drawings, then they could learn it without necessarily knowing all the language behind it. They need to know a little bit, but I think the pictures and gestures help to support it a lot.

Ophelia believed that ELs would be able to learn mathematics since "a lot of math can be demonstrated without using words." This indicated her belief that mathematics involved mostly numbers, symbols, and operations, that captured the essence of the belief of mathematics being universal. Her use of "without using words" points to her belief that ELs had a language barrier; thus, the need to moderate speech. She also believed that ELs could be taught mathematics with early levels of English proficiency using other modes like pictures and drawings, once again emphasizing her belief about mathematics being universal to even make that possible. Her belief for this item that mathematics is universal was conditioned on the assumption that ELs had "a grounding" in mathematics from their home country. In both the responses of Sandra and Ophelia, though there is one dominant belief that comes into play when they respond to the item, the other beliefs in the collection influence their thinking. The dominance of one belief in the collection was also noted in the PSTs' responses to other items. We could not identify a pattern to the dominance of beliefs. The same PST could have the belief that ELs have a language barrier in English dominate their response to an item, and their belief that mathematics is universal dominate their response to another item. We thus see a complex relationship among beliefs in the collection as they relate to dominance.

Convergence. The third type of belief interaction was the convergence of primary beliefs. The convergence of the beliefs in the collection usually indicated strong reactions on the Likert scale from the PST (Strongly Agree/Disagree). For example, the PSTs believed that the use of modes other than speech, like manipulatives and gestures, could be useful for the ELs to demonstrate their thinking (item 10). This combined the beliefs in the collection - mathematics is universal and language barrier, as the PSTs responded to the item. Note that in the interviews the PSTs mentioned that they also believed that the nonverbal modes were useful for all students, not just the ELs. However, given their belief that the ELs had a language barrier in English, the use of the nonverbal modes by the ELs was even more important to demonstrate their thinking.

We also observed the convergence of beliefs in the collection when PSTs were asked about the use of the native language in the mathematics classroom (item 12). In this study, most of the PSTs agreed to some use of the ELs' native language in the mathematics class, as they believed that allowing the use of the native language would help the students connect with the mathematics that they learned in their home countries. More specifically, the PSTs believed that the ELs could make connections to the mathematics vocabulary that they learned in their native language. Here we observe the interaction between their beliefs - ELs have a language barrier, mathematics is universal, and mathematical language primarily consists of vocabulary, all pulling together as PSTs respond to the use of the native language by ELs in the mathematics class. When asked about the use of the native language in the class, Ophelia responds,

I agree (with item 12). As long as it's like the question says, new ELs. I think if they are just learning it (English), then they need to be taught in their native language and English. Because if you just start talking to them in English about it, they're not going to understand and they're not going to be able to make connections between the math vocabulary in their native language and math vocabulary in English. 
Cause a lot of the math vocabulary, they probably already know, but they just don't know it in English. So, I think it is important to make those connections of the math vocabulary in their native language versus in English. But I think like once they get a little bit better in English, I think it needs to be all English.

Ophelia, like most of the PSTs, was eager for the ELs to assimilate into U.S. schooling with English as the language of teaching. She believed that mathematics was universal and along with the mathematical vocabulary, was significant for the ELs to overcome their barriers with English and understand the mathematical ideas. This contrasted to the use of the EL students' native language as a resource. Where the native language was used to facilitate interactions and the building of meaning, the PSTs seem to view the use of the native language as a means to connect to mathematics vocabulary that they learned in their native language. Like Ophelia, most of the PSTs believed that there were benefits to allowing limited use of the native language in the class for making the connections to the previous mathematics learned, primarily through the vocabulary.

Tension. There were seven instances of tension among the beliefs in the collection. Usually, the tensions were manifested in the PSTs choosing to be undecided on the Likert scale. The tension between the belief that mathematics is universal and the belief that ELs have a language barrier in English, is brought out in the case of Ingrid, a middle grade PSTs as she responds to mathematics being the best subject to transition ELs into learning English (item 5):

I know math is universal, numbers are the same everywhere but I'm not quite sure that it would be the best in helping them begin to use English. But at the same time since math is universal then it might be best because they can relate to the numbers and stuff like that.

On the one hand she believed that mathematics would not be the best subject to transition into English since, given their language barrier, the ELs would need a more immersive experience in learning English. Mathematics classes could not provide this immersion in English. On the other hand, she believed that mathematics was universal, involving numbers, and would be the ideal subject to transition the ELs. The tension in this case resulted in Ingrid remaining undecided on the item. In our analysis of the interviews, we believe that there would be more instances of tensions, however, the format of the interview of using a Likert scale seemed to influence the PSTs' responses where they may have felt the need to make a choice, resulting in dominance being the most frequent way in which the beliefs in the collection interacted.

\subsection{A counter example}

There was one elementary PST, Ginny, who had some primary beliefs that did not align with those described so far. She had 5-10 years teaching experience, mostly with ELs, and had been exposed to EL issues in her coursework. One of her parents spoke Polish and she regretted not learning the language herself. The main difference between Ginny and the other PSTs was that she did not believe, and actively pushed back against, the belief that ELs had a language barrier with English. Instead she viewed all the linguistic resources of the ELs as resources that she could draw on in teaching. Referring to the use of the students' native language she added, "I think it's amazing if they switch between two languages, I'm actually more impressed because they are getting it in two languages." Later in the same response she indicated that it is important for the ELs to maintain their native language. She says, "I don't want them to think that one is more [important], they are both equally important. I'm not gonna expect English at the 
detriment of their home language. I will not do that." Showing the EL students that their native language was valued in the class and that the EL students were valued members. Ginny also contrasted to the other PSTs in her belief about the nature of mathematics. While the other PSTs who believed that there were linguistic aspects in mathematics, they believed that these were separate to the numbers, which were more dominant in mathematics, Ginny did not separate the numbers and the mathematical language. When asked if mathematics is language intensive (item 1), as part of her response she added,

I think math sometimes is more intensive than reading is because it is so content specific and you have to... it's not only just understanding the concepts but understanding the academic language that goes along with it.

Ginny believed that she could scaffold the language to support the ELs engaged with mathematics in the classroom. She also acknowledged that it would take the ELs 5 -7 years to become proficient in the academic language in mathematics. In Ginny's case, her collection of beliefs acted in convergence as she reasoned through the items. Her reasoning highlighted her beliefs about mathematics and language being intertwined, drawing on the students' linguistic resources, and providing the scaffolding needed for the ELs to engage in the classroom with the curricular content.

\section{Discussion}

We found that most of the PSTs had three beliefs (mathematics is universal, mathematical language, and language barrier) that formed their collection of beliefs in the context of teaching mathematics to ELs. We also noted three ways in which these beliefs interacted in the collection as the PSTs responded to the items: dominance, tension, and convergence. Like Aguirre and Speer (1999) and Speer (2008), we see that beliefs from different clusters of beliefs about mathematics, language, and English learners, come together to inform the PSTs' responses. This study extends the construct of collections of beliefs from prior work on beliefs as individual categories in the context of teaching mathematics to ELs. Further, the study provides evidence of how the beliefs in the collection interact with each other. Based on the results, especially the case of Ginny, we see that the beliefs converge to inform issues of practice. We conjecture that teachers may first experience a dominance of one belief, then move to a tension of beliefs, and finally to convergence. Future research can examine these interactions.

Though our focus was on the collection of beliefs, we observed relationships between primary beliefs of the PSTs and prior beliefs reported in the literature regarding, for instance, the fact that teachers believed mathematics was the easiest school subject because it was universal (e.g. Sawyer, 2000). In our study the PSTs believed that mathematics was universal, however, it would be challenging for the ELs, just like it is for all the students. PSTs in this study described the ELs as knowing mathematics and believed that they could transfer this knowledge when they were learning mathematics in U.S. classrooms, with vocabulary playing a key role. PSTs' beliefs about transfer were like teachers' beliefs about principles of bilingualism reported in the literature (e.g. Shin \& Krashen, 1996). However, the PSTs' beliefs in this study contrast with prior reports of teachers who believed that ELs came from inferior education systems, or that ELs did not do well in school (e.g. Walker, Shafer, \& Iiams, 2004).

The PSTs in this study assumed that the ELs were recent immigrants to the country and would have a language barrier when communicating in English. We understand that the use of the term English learner, though used officially in the U.S., is problematic since the PSTs assumed that the ELs were a homogeneous group of recent immigrants. 
As such, the PSTs did not consider that students labeled as EL could have varying language proficiencies. While some ELs are born in the U.S. and considered long-term ELs after receiving language services for six years or more. they are challenged with the use of the academic language in the mathematics classroom. We observed that the term EL prompted deficit views about language. Along with the belief that ELs were recent migrants and had a language barrier in English, the PSTs demonstrated some ideological beliefs about language and had a distinct preference to assimilate ELs into English within a school year. Just like teachers in prior studies, they were concerned that allowing ELs to use their native language in the long run could hamper their learning of English (e.g. Youngs \& Youngs, 2001). Ginny was the only PST who strongly promoted the use of the native language in the mathematics class and bilingualism. Even though the PSTs believed that ELs could transfer mathematics knowledge learned in the native language to English dominant lessons, they were not eager that ELs should be taught mathematics in the home language and English. Overall PSTs believed that mathematics lessons should focus on mathematics content and not on language development, and called for and support classes with an immersive experience in English.

We are aware that the design of the interview and of the survey items mediated our findings. The terminology and the wording of the item impacted the way the PSTs interpreted and responded to the items. For example, in item 6, the use of the word "effectively" seemed to be interpreted in slightly different ways by the PSTs and could account for some of the variation in their responses. It was challenging to determine, even after interacting with the PSTs, if they were thinking about effective mathematics instruction in similar ways. We tried to gain a better understanding by interacting with the PSTs extensively during the interview and across many items. We used the term EL given its familiarity with the PSTs. However, the use of the term seemed to prompt a deficit focus, with most of the PSTs, on what the students lacked, namely English. This could be an impediment to a more resource-oriented approach. We think that using the term emerging bilingual, though appropriate, would be unfamiliar and could lead to some confusion in the PSTs' responses. An overall lack of familiarity of the PSTs with the terminology in the area (like conversational language and academic language) could have constrained the meaning in their responses. That said, we believe that asking the PSTs to provide detailed descriptions, in addition to the examples they provided, and the questioning, helped mitigate the lack of familiarity with the terminology. In the end, beliefs are always an interpretation of the researchers.

\section{Acknowledgements}

This research was partially supported by The Faculty Research Grant at the University of North Carolina Charlotte. The views expressed are those of the authors and are not reflective of the funding agency.

\section{References}

Aguirre, J., \& Speer, N. M. (1999). Examining the relationship between beliefs and goals in teacher practice. The Journal of Mathematical Behavior, 18, 327-356.

Civil, M. (2007). Building on community knowledge: An avenue to equity in mathematics education. In N. Nasir \& P. Cobb (Eds.), Improving access to mathematics: Diversity and equity in the classroom (pp. 105-117). New York: Teachers College Press. 
Cooney, T. J., \& Shealy, B. E. (1997). On understanding the structure of teachers' beliefs and their relationship to change. In E. Fennema, \& B. Nelson (Eds.), Mathematics teachers in transition (pp. 87-109). Mahwah, NJ: Lawrence Erlbaum.

Cooney, T., Shealy, B., \& Arvold, B. (1998). Conceptualizing belief structures of preservice secondary mathematics teachers. Journal for Research in Mathematics Education, 29, 306-333.

Cross, D. I. (2009). Alignment, cohesion, and change: Examining mathematics teachers' belief structures and their influence on instructional practices. Journal of Mathematics Teacher Education, 12, 325-346.

Cummins, J. (2000). Language, power, and pedagogy: Bilingual children in the crossfire. Buffalo, NY: Multilingual Matters.

Gandára, P., Maxwell-Jolly, J., \& Driscoll, A. (2005). Listening to teachers of English language learners: A survey of California teachers' challenges, experiences, and professional development needs. Santa Cruz, CA: Center for the Future of Teaching and Learning.

Fernandes, A. (2020). The language orientations of future mathematics teachers in the United States. REDIMAT, 9, 7-29.

Glaser, B. G., \& Strauss, A. L. (2017). Discovery of grounded theory: Strategies for qualitative research. New York: Routledge.

González, J. M., \& Darling-Hammond, L. (2000). New concepts and new challenges: Professional development for teachers of immigrant youth. Washington, DC: Center for Applied Linguistics.

Green, T. G. (1971). The activities of teaching. New York: McGraw Hill.

Griego-Jones, T. (2002). Relationship between pre-service teachers' beliefs about second language learning and prior experiences with non-English speakers. In L. Minaya-Rowe (Ed.), Teacher training and effective pedagogy in the context of student diversity (pp. 39-64). Greenwich, CT: IAP.

Gutiérrez, R. (2002). Beyond essentialism: The complexity of language in teaching mathematics to Latina/o students. American Educational Research Journal, 39(4), 1047-1088.

Karabenick, S. A., \& Noda, P. A. C. (2004). Professional development implications of teachers' beliefs and attitudes toward English language learners. Bilingual Research Journal, 28(1), 55-75.

Moschkovich, J., \& Zahner, W. (2018). Using the academic literacy in mathematics framework to uncover multiple aspects of activity during peer mathematical discussions. ZDM-Mathematics Education, 50, 999-1011.

Pajares, M. F. (1992). Teachers' beliefs and educational research: Cleaning up a messy construct. Review of Educational Research, 62, 307-332.

Penfield, J. (1987). ESL: The regular classroom teacher's perspective. TESOL Quarterly, 21, 21-39.

Philipp, R. (2007). Mathematics teachers' beliefs and affect. In F. Lester (Ed.), Second handbook of research on mathematics teaching and learning (Vol 1., pp. 257-315). Reston, VA: NCTM. 
Polat, N., \& Mahalingappa, L. (2013). Pre- and in-service teachers' beliefs about ELLs in content area classes: A case for inclusion, responsibility, and instructional support. Teaching Education, 24, 58-83.

Reeves, J. R. (2006). Secondary teacher attitudes toward including English-language learners in mainstream classrooms. Journal of Educational Research, 99, 131-142.

Ruiz, R. (1988). Orientations in language planning. In S. McKay, \& S. Wong (Eds.), Language diversity: Problem or resource? (pp. 3-25). Cambridge, MA: Newbury.

Sawyer, R. D. (2000). Adapting curriculum to student diversity: Patterns and perceptions among alternate-route and college-based teachers. The Urban Review, 32, 343-363.

Shin, F. H., \& Krashen, S. (1996). Teacher attitudes toward the principles of bilingual education and toward students' participation in bilingual programs: Same or different? Bilingual Research Journal, 20, 45-53.

Speer, N. (2005). Issues of methods and theory in the study of mathematics teachers' professed and attributed beliefs. Educational Studies in Mathematics, 58, 361-391.

Speer, N. (2008). Connecting beliefs and practices: A fine-grained analysis of a college mathematics teacher's collections of beliefs and their relationship to his instructional practices. Cognition and Instruction, 26(2), 218-267.

Sztajn, P. (2003). Adapting reform ideas in different mathematics classrooms: Beliefs beyond mathematics. Journal of Mathematics Teacher Education, 6, 53-75.

Tan, M. (2011). Mathematics and science teachers' beliefs and practices regarding the teaching of language in content learning. Language Teaching Research, 15, 325342.

Thompson, A. (1984). The relationship of teachers' conceptions of mathematics teaching to instructional practice. Educational Studies in Mathematics, 15, 105-127.

Thompson, A. (1992). Teachers' beliefs and conceptions: A synthesis of the research. In D. A. Grouws (Ed.), Handbook of research on mathematics teaching and learning (pp. 127-146). New York: Macmillan.

Walker, A., Shafer, J., \& Iiams, M. (2004). "Not in my classroom": Teacher attitudes towards English language learners in the mainstream classroom. NABE Journal of Research and Practice, 2(1), 130-160.

Yoon, B. (2007). Classroom teachers' understanding of the needs of English-language learners and the influence on the students' identities. The New Educator,3, 221-240.

Youngs, C. S., \& Youngs Jr, G. A. (2001). Predictors of mainstream teachers' attitudes toward ESL students. TESOL Quarterly, 35, 97-120.

Zazkis, R., \& Hazzan, O. (1999). Interviewing in mathematics education: Choosing the questions. The Journal of Mathematical Behaviour, 17, 429-439.

\section{Authors' contact details}

Anthony Fernandes, University of North Carolina at Charlotte (USA).

anthony.fernandes@uncc.edu

Leslie H. Kahn, Tucson Unified School District (USA). 1kahn1 @ mindspring.com 


\title{
Preservice teachers' beliefs in the context of teaching mathematics to English learners in the United States
}

\author{
Anthony Fernandes, University of North Carolina at Charlotte \\ Leslie H. Kahn, Tucson Unified School District
}

This study examines the beliefs of fourteen preservice teachers in the Southeast United States about mathematics and language in the context of teaching mathematics to English learners. Qualitative interviews were conducted using survey items as a starting point for the questioning. Ten were one-on-one and two interviews were conducted in pairs due to scheduling constraints. Speer's (2008) construct of collections of beliefs was used to understand the preservice teachers' belief system and the interaction of beliefs. The construct of collection of beliefs captures the small set of beliefs that together describe a teacher's perspective on a particular topic. We found that most of the preservice teachers had three beliefs (mathematics is universal, mathematical language, and language barrier) that formed their collection of beliefs in the context of teaching mathematics to ELs. Their belief about mathematics being universal was grounded in their view that mathematics was mostly about symbols and equations. The preservice teachers believed that there was some language in mathematics, though these features were not as pervasive as the symbolic form. Most of them also believed that the English learners were recent immigrants to the country and that English was a barrier for the students in the mathematics classroom. Further, the study provided evidence of how the beliefs in the collection interact with each other. The beliefs interacted in three ways as they responded to the items: dominance, tension, and convergence. We conjecture that teachers may first experience a dominance of one belief, then move to a tension of beliefs, and finally to convergence. We overall found that beliefs from different clusters of beliefs about mathematics, language, and English learners, come together to inform the preservice teachers' responses. Understanding beliefs as a collection has implications for preparing mathematics teachers to work with English learners in their future classrooms in the United States, but also for mathematics teachers to work with learners of the language of instruction throughout the world regions. 